\title{
A model for chronic, intrahypothalamic thyroid hormone administration in rats
}

\author{
Z Zhang1, P H Bisschop', E Foppen', H C van Beeren', A Kalsbeek1, 2, A Boelen' \\ and E Fliers ${ }^{1}$ \\ 1Department of Endocrinology and Metabolism, Academic Medical Center (AMC), University of Amsterdam, \\ Amsterdam, the Netherlands \\ ${ }^{2}$ Hypothalamic Integration Mechanisms, Netherlands Institute for Neuroscience (NIN), Amsterdam, \\ Amsterdam, the Netherlands
}

Correspondence

should be addressed

to Z Zhang

Email

z.zhang@amc.uva.nl

\begin{abstract}
In addition to the direct effects of thyroid hormone (TH) on peripheral organs, recent work showed metabolic effects of TH on the liver and brown adipose tissue via neural pathways originating in the hypothalamic paraventricular and ventromedial nucleus (PVN and VMH). So far, these experiments focused on short-term administration of $\mathrm{TH}$. The aim of this study is to develop a technique for chronic and nucleus-specific intrahypothalamic administration of the biologically active $\mathrm{TH}$ tri-iodothyronine $\left(\mathrm{T}_{3}\right)$. We used beeswax pellets loaded with an amount of $\mathrm{T}_{3}$ based on in vitro experiments showing stable $\mathrm{T}_{3}$ release $\left(\sim 5 \mathrm{nmol} \mathrm{I}^{-1}\right)$ for 32 days. Upon stereotactic bilateral implantation, $\mathrm{T}_{3}$ concentrations were increased 90 -fold in the $\mathrm{PVN}$ region and 50 -fold in the $\mathrm{VMH}$ region after placing $\mathrm{T}_{3}$-containing pellets in the rat $\mathrm{PVN}$ or $\mathrm{VMH}$ for 28 days respectively. Increased local $\mathrm{T}_{3}$ concentrations were reflected by selectively increased mRNA expression of the $\mathrm{T}_{3}$-responsive genes Dio3 and $\mathrm{Hr}$ in the PVN or in the $\mathrm{VMH}$. After placement of $\mathrm{T}_{3}$-containing pellets in the PVN, Tshb mRNA was significantly decreased in the pituitary, without altered Trh mRNA in the PVN region. Plasma $T_{3}$ and $\mathrm{T}_{4}$ concentrations decreased without altered plasma TSH. We observed no changes in pituitary $\mathrm{Tsh} b$ mRNA, plasma $\mathrm{TSH}$, or plasma $\mathrm{TH}$ in rats after placement of $\mathrm{T}_{3}$-containing pellets in the $\mathrm{VMH}$. We developed a method to selectively and chronically deliver $\mathrm{T}_{3}$ to specific hypothalamic nuclei. This will enable future studies on the chronic effects of intrahypothalamic $\mathrm{T}_{3}$ on energy metabolism via the PVN or $\mathrm{VMH}$.
\end{abstract} Key Words

Journal of Endocrinology (2016) 229, 37-45

\section{Introduction}

Thyroid hormone (TH) is a major determinant of basal metabolic rate as well as glucose and lipid metabolism (Mullur et al. 2014, Sinha et al. 2014). A number of recent studies have shown that in addition to the well-known direct effects of TH at the tissue level, some of its metabolic effects are mediated indirectly through specific neuronal targets within the hypothalamus. In particular, this has been shown in rats for hepatic glucose metabolism, brown adipose tissue (BAT) function, and the central
(C) 2016 Society for Endocrinology Printed in Great Britain control of blood pressure and heart rate (for reviews see Fliers et al. 2010, Warner \& Mittag 2012, Lopez et al. 2013). Studies on rats have shown that thyrotoxicosis increases glucose production in the liver, while reducing hepatic insulin sensitivity. These effects appeared to be modulated by selective hepatic sympathetic and parasympathetic denervation (Klieverik et al. 2008), and follow-up experiments showed that $\mathrm{TH}$ stimulates hepatic glucose production via a sympathetic pathway

Published by Bioscientifica Ltd 
originating in the hypothalamic paraventricular nucleus (PVN) (Klieverik et al. 2009). Similarly, indirect effects of TH on BAT via the hypothalamic ventromedial nucleus (VMH) were reported by several groups. First, mice heterozygous for a mutant TR $\alpha 1$ with low affinity for $\mathrm{T}_{3}$ appeared to be hypermetabolic due to increased BAT activity, resulting in increased thermogenesis and energy expenditure. The metabolic phenotype was blunted after a functional denervation of sympathetic signaling, suggesting that the central nervous system (CNS) controlled the hypermetabolism of these mice through the autonomic nervous system (Sjogren et al. 2007). More recently, López and coworkers showed that activation of the thermogenic program in BAT through the sympathetic nervous system (SNS) depends on $\mathrm{T}_{3}$-mediated activation of de novo lipogenesis in the hypothalamic VMH (Lopez et al. 2010), establishing a role for $T_{3}$ in the VMH in the regulation of BAT. Together, these studies revealed a distinct role of hypothalamic $T_{3}$ in the regulation of peripheral organs through the autonomic nervous system.

It should be noted that the above-mentioned metabolic effects of intrahypothalamic $T_{3}$ were observed in acute experiments, i.e., a few hours after $\mathrm{T}_{3}$ administration, whereas metabolic dysfunction in thyrotoxicosis, including insulin resistance and weight loss, is mostly due to long-term exposure to excessive TH. Thus, the relationship between chronically elevated intrahypothalamic $T_{3}$ concentrations and metabolic dysfunction, which may be of clinical relevance, has not been reported yet. Before embarking on experiments to explore this relationship, we aimed to develop a method for selective and chronic (4 weeks) administration of $\mathrm{T}_{3}$ in the rat $\mathrm{PVN}$ or $\mathrm{VMH}$ region.

We implanted $\mathrm{T}_{3}$-containing or control pellets bilaterally into either the PVN or the VMH region of rats for a period of 28 days. Plasma $\mathrm{T}_{3}, \mathrm{~T}_{4}$, and TSH concentrations were measured at regular time intervals after placement of the pellets. Hypothalamic tissue punches containing either the PVN or the VMH, as well as pituitary glands, were collected at the end of the experiment for the assessment of local $\mathrm{T}_{3}$ tissue concentration and gene expression analysis. We conclude from our experiments that it is feasible to deliver $T_{3}$ selectively and chronically to distinct hypothalamic nuclei.

\section{Materials and methods}

\section{Preparation of pellets}

3,3'5-tri-iodo-L-thyronine (Sigma-Aldrich) was mixed with melted beeswax (Sigma-Aldrich) at a ratio of 1:9 (w/w) in a $70^{\circ} \mathrm{C}$ water bath. The mixture was packaged into a length of $1 \mathrm{~mm}$ cylindrical pellet using a $23 \mathrm{G}$ stainless cannula. The weight of the pellets was around $76.8 \mu \mathrm{g}$, including $10 \%$ of $\mathrm{T}_{3}$ amounting to $7.68 \mu \mathrm{g}$. Blank beeswax pellets without $\mathrm{T}_{3}$ were used as control pellet. During surgery, the pellet was extruded out of the cannula by a stainless steel wire plunder.

\section{In vitro experiment}

$\mathrm{T}_{3}$-containing pellets $\left(\mathrm{T}_{3} \mathrm{Ps}\right)$ or control pellets (cPs) were incubated in $500 \mu \mathrm{l}$ bovine serum on a $37^{\circ} \mathrm{C}$ homoeothermic shaker for 28 days. After 1 day and every 3 days thereafter, a sample of $250 \mu$ l serum was taken from the system for assessment of $\mathrm{T}_{3}$ concentration and replaced by an equal amount of fresh serum.

\section{Animal experiments}

Male Wistar rats weighting 280-320g (total number 92; Charles River Breeding Laboratories, Sulzfeld, Germany) were housed individually in a $12 \mathrm{~h}$ light: $12 \mathrm{~h}$ darkness cycle environment. Chow and water were provided ad libitum. All procedures were approved by the Animal Care Committee of the Royal Netherlands Academy of Arts and Sciences.

After 1 week of acclimatization in the facility, a total number of 84 animals divided into eight groups (see Table 1) were anesthetized by an intramuscular injection of Hypnorm (fentanyl, $0.252 \mathrm{mg} / \mathrm{kg} \mathrm{BW}$; fluanisone, $8 \mathrm{mg} / \mathrm{kg}$ BW; Janssen, High Wycombe, Buckinghamshire, UK) followed by a subcutaneous Midazolam ( $1 \mathrm{mg} / \mathrm{kg}$ BW; Roche) injection. $\mathrm{T}_{3} \mathrm{Ps}$ or cPs were implanted bilaterally into the hypothalamic PVN (anteroposterior: $-1.8 \mathrm{~mm}$; lateral: $2.1 \mathrm{~mm}$; ventral: $-6.9 \mathrm{~mm}$; angle: $10^{\circ}$ ) or $\mathrm{VMH}$ (anteroposterior: $-2.3 \mathrm{~mm}$; lateral: $2.2 \mathrm{~mm}$; ventral: $-8.1 \mathrm{~mm}$; angle: $10^{\circ}$ ) region using a standard Kopf stereotaxic apparatus (Paxinos \& Watson 2005). Pellet placements were checked in $20 \mu \mathrm{m}$ cresyl violet-stained brain sections of each animal at the end of the experiment. Blood samples (around $250 \mu \mathrm{l}$ ) were taken by tail incisions using heparin-coated capillary Microvette (Sarstedt AG \& Co, Nümbrecht, Germany) 3 days before and 3, 7, 14,21 , and 28 days after pellet placement. The plasma samples were collected after centrifugation at $4000 \mathrm{rpm}$ for $15 \mathrm{~min}$ and stored at $-20^{\circ} \mathrm{C}$. After 28 days, rats were decapitated; trunk blood was taken and stored at $-20^{\circ} \mathrm{C}$ until analysis. Pituitaries were snap frozen in liquid nitrogen and stored in $-80^{\circ} \mathrm{C}$ until further use.

Published by Bioscientifica Ltd. 
Table 1 Design of the experimental groups.

\begin{tabular}{|c|c|c|}
\hline No. & Group & Treatment \\
\hline 1 & Intact & Untreated \\
\hline 2 & CP_PVN & Control pellets in the PVN \\
\hline 3 & $\mathrm{~T}_{3} \bar{P}_{-} \mathrm{PVN}$ & $\mathrm{T}_{3}$-containing pellets in the PVN \\
\hline 4 & $\mathrm{CP} \_\mathrm{VMH}$ & Control pellets in the $\mathrm{VMH}$ \\
\hline 5 & $\mathrm{~T}_{3} \bar{P}_{-} \mathrm{VMH}$ & $\mathrm{T}_{3}$-containing pellets in the $\mathrm{VMH}$ \\
\hline 6 & CP_PVN & Control pellets in the PVN \\
\hline 7 & $\mathrm{~T}_{3} \bar{P}_{-} \mathrm{PVN}$ & $\mathrm{T}_{3}$-containing pellets in the PVN \\
\hline 8 & $\mathrm{CP}_{-} \mathrm{VMH}$ & Control pellets in the $\mathrm{VMH}$ \\
\hline 9 & $\mathrm{~T}_{3} \bar{P}_{-} \mathrm{VMH}$ & $\mathrm{T}_{3}$-containing pellets in the $\mathrm{VMH}$ \\
\hline
\end{tabular}

\begin{tabular}{c}
\hline Group size \\
\hline 8 \\
8 \\
12 \\
8 \\
12 \\
11 \\
11 \\
11 \\
11
\end{tabular}

Description
For $q P C R$ in hypothalamic punches
For $\mathrm{T}_{3}$ brain tissue concentrations

Brains were removed and frozen on dry ice. The hypothalamus was cut into $300 \mu \mathrm{m}$ coronal sections using a cryostat (Leica CM1950). For $\mathrm{T}_{3}$ tissue concentration and gene expression measurements, the PVN and $\mathrm{VMH}$ regions were collected by punching the area with a $17 \mathrm{G}$ stainless steel needle according to Palkovits (1973). The third ventricle and major fiber tracts served as landmarks for orientation. Tissue was then homogenized either in lysis buffer (Roche Applied Science, Penzberg, Germany) for RNA isolation or in PBS for the assessment of tissue $\mathrm{T}_{3}$ concentration. Validation of the punched blocks was performed by measuring the expression levels of nucleus-specific genes by qPCR.

\section{Plasma thyroid hormones}

Plasma $\mathrm{T}_{3}$ and $\mathrm{T}_{4}$ concentrations were determined using an in-house RIA as reported before (inter-assay variation $\mathrm{T}_{3}$, $6.2 \%$ and $\mathrm{T}_{4}, 7.3 \%$; intra-assay variability $\mathrm{T}_{3}, 3.6 \%$ and $\mathrm{T}_{4}, 6.6 \%$ ) (Wiersinga \& Chopra 1982). Plasma TSH was determined by a chemiluminescent immunoassay, using the Immulite 2000 (Siemens). For TSH, the inter-assay variation was $\pm 9 \%$ and the intra-assay variation was $3-4 \%$.
Within the same experiment, all samples were measured within one run to prevent inter-assay variation.

\section{Hypothalamic tissue $T_{3}$ concentrations}

The PVN and VMH punches were weighed and homogenized in 300 $\mu \mathrm{l}$ methanol using a Magna Lyser (Roche Molecular Biochemicals, Mannheim, Germany). The homogenates were then extracted using a double volume of chloroform. The mixtures were centrifuged at $3184 \boldsymbol{g}$ at $4^{\circ} \mathrm{C}$ for $15 \mathrm{~min}$. Supernatants from the extractions were transferred into glass vials and vaporized under nitrogen gas for $30 \mathrm{~min}$. Subsequently, samples were dissolved in $70 \mu \mathrm{l}$ alkaline $\mathrm{T}_{3}$ RIA assay buffer and $70 \mu \mathrm{l} \mathrm{T}_{3}$-free plasma. $\mathrm{T}_{3}$ concentrations were measured by $\mathrm{T}_{3}$ RIA as described above.

\section{RNA isolation and real-time PCR (qPCR)}

Total RNA from pituitary, the PVN, and VMH punches were isolated using the MagNA Pure LC 2.0 Instrument (Roche Molecular Biochemicals) with Magna pure tissue III total RNA kit (Roche Molecular Biochemicals). RNA yield was determined using the Nanodrop (Nanodrop),

Table 2 Primers used for qPCR.

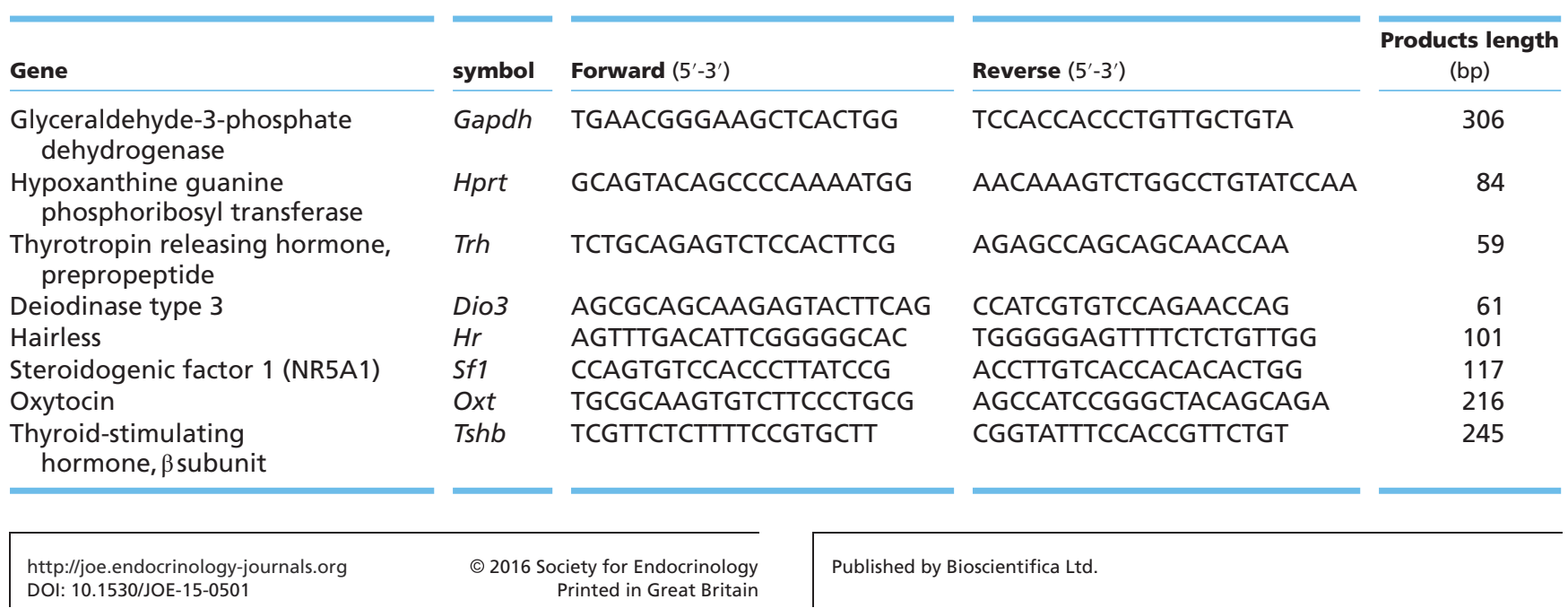




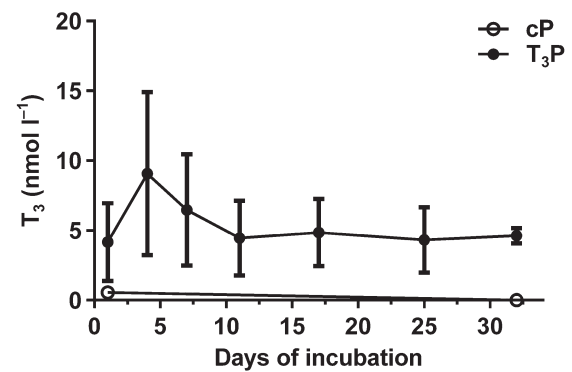

Figure 1

$\mathrm{T}_{3}$-containing pellets result in rather stable $\mathrm{T}_{3}$ concentrations in the medium for $>30$ days. Open circles denote control pellets (CP) and solid circles denote $T_{3}$-containing pellets $\left(T_{3} P\right)$. Mean \pm S.E.M. of three pellets/ group are depicted.

and cDNA was synthesized with equal RNA input with the First-Strand cDNA synthesis kit (AMV) for qPCR with oligo-d (T) primers (Roche Molecular Biochemicals). As a control for genomic DNA contamination, a cDNA synthesis reaction without reverse transcriptase was included. Quantitative PCR was performed using the LightCycler 480 (Roche Molecular Biochemicals) and LightCycler 480 SYBR Green I Master mix (Roche Molecular Biochemicals). The primers used for qPCR are listed in Table 2. Quantification was performed using the LinReg software. PCR efficiency was checked individually and samples with a deviation of more than $5 \%$ of the mean were excluded from the analysis. Calculated values were related to the geometric mean expression of Gapdh and Hprt, reference genes showing stable expression under the experimental conditions.

\section{Statistical analysis}

Data are expressed as mean \pm standard error of the mean (s.E.M.). Differences between two groups were analyzed using an independent two-tailed Student's t-test. When data were not normally distributed, the independent nonparametric Mann-Whitney $U$ test was used. The changes in $\mathrm{T}_{3}$ and $\mathrm{T}_{4}$ concentrations in the plasma were evaluated by two-way ANOVA with repeated measurements followed by Bonferroni post hoc analysis. Statistical significance was defined at a level of $p<0.05$.

\section{Results}

\section{In vitro experiments}

Before the in vivo experiments, we tested the release of $\mathrm{T}_{3}$ from $\mathrm{T}_{3} \mathrm{P}$ in serum. The in vitro results showed that $\mathrm{T}_{3}$ was constantly released into the medium at a concentration of $\sim 5 \mathrm{nmol} \mathrm{l}^{-1}$ from the $\mathrm{T}_{3} \mathrm{P}$ (corresponding to a $\mathrm{T}_{3}$ release of around $0.26 \mathrm{ng}$ per day), but not from cP for a period of 32 days (Fig. 1).
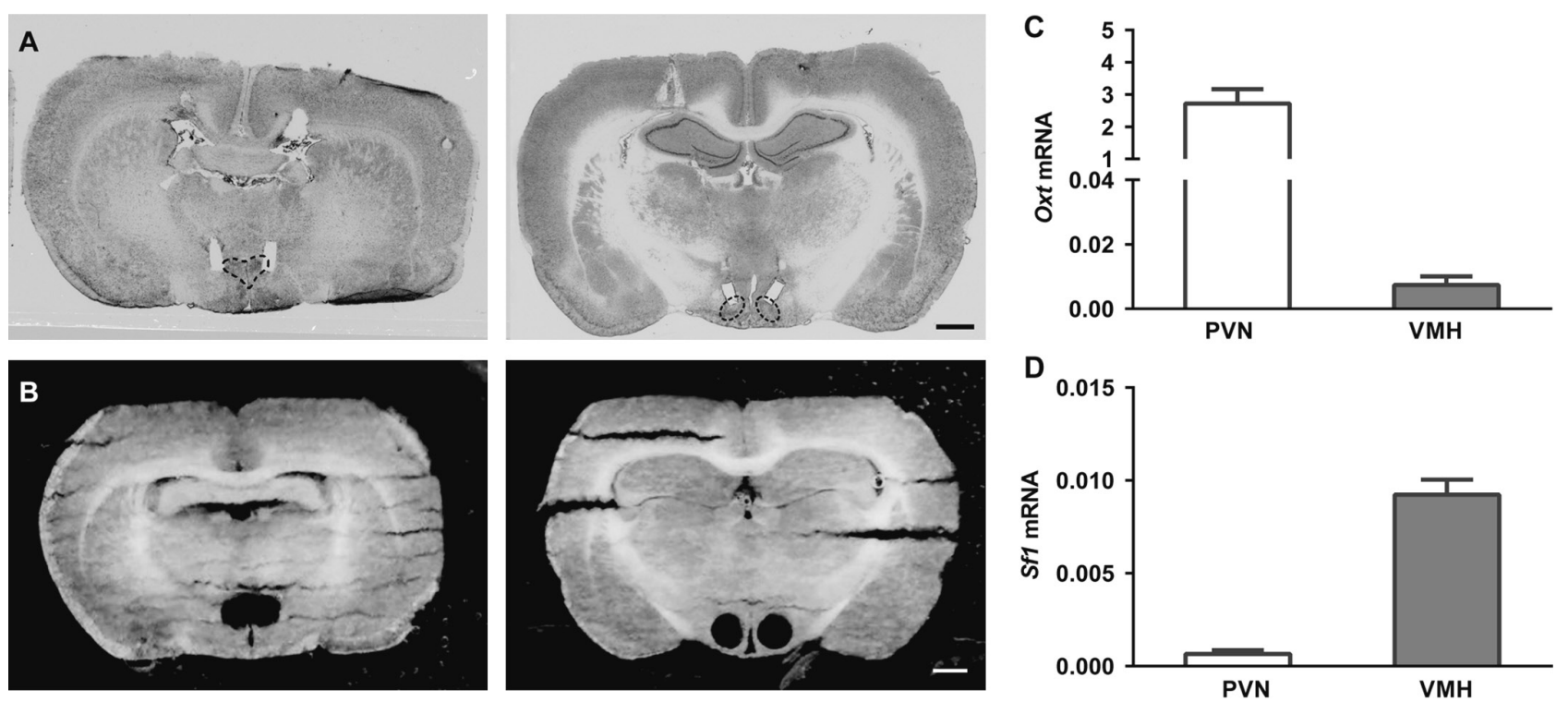

Figure 2

Representative photomicrographs of brain sections, showing the location and size of the pellet implants (A) and of the micro-punches (B) in the PVN (left panel) and VMH (right panel). Scale bars represent $1 \mathrm{~mm}$. (C) shows Oxt mRNA expression in the PVN and VMH punches and (D) shows Sf1 mRNA expression in the PVN and VMH punches. $n=8$ per group. 

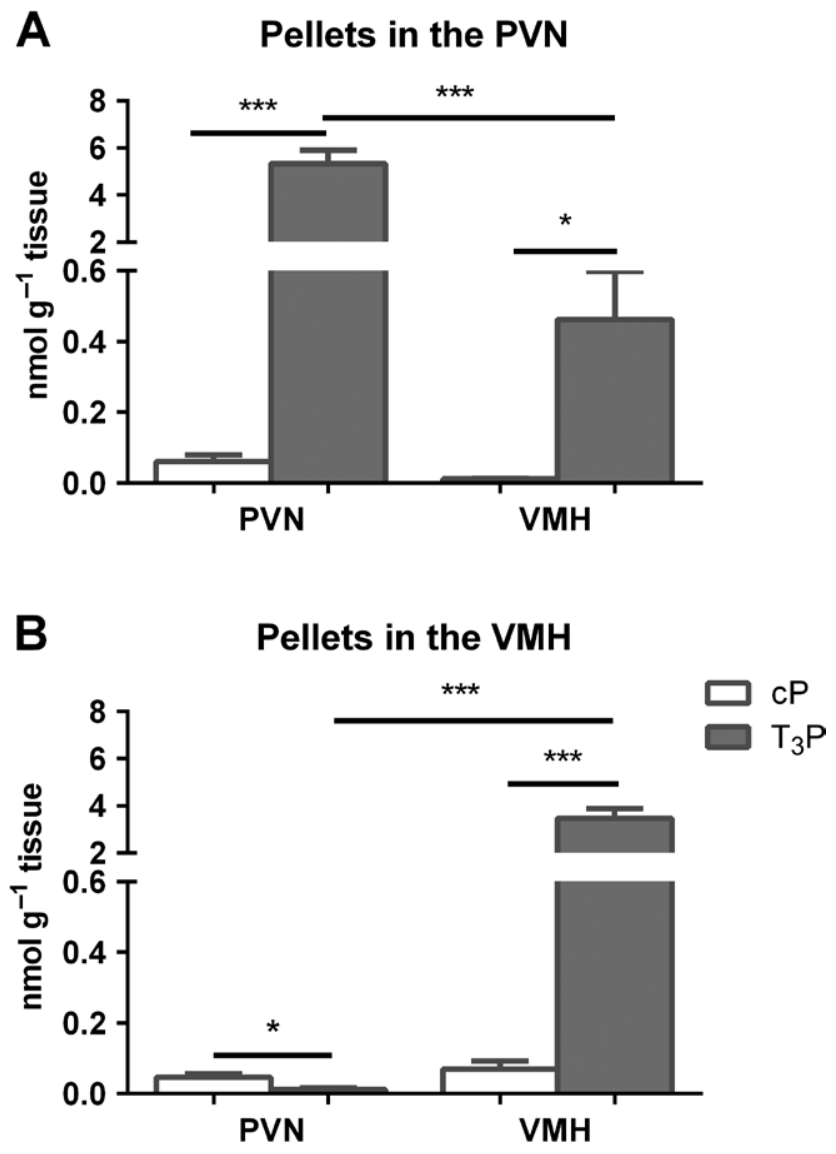

Figure 3

Local $\mathrm{T}_{3}$ concentrations ( $\mathrm{nmol} \mathrm{g}^{-1}$ brain tissue) in the PVN and $\mathrm{VMH}$ regions. (A) pellets were placed in the PVN, (B) pellets were placed in the VMH. $n=8-9$ per group. ${ }^{*} P<0.05, * * * P<0.001$.

\section{Pellet placement and validation of hypothalamic dissection}

$\mathrm{T}_{3}$ Ps or cPs were placed either in the PVN or in the VMH. Post-mortem examination revealed that the majority of pellets were placed laterally from the PVN and dorsolaterally in the $\mathrm{VMH}$ with an anteroposterior location ranging from -1.0 to $-1.7 \mathrm{~mm}$ from bregma (Fig. 2). Nine animals were excluded from the analysis because of the misplacement of the pellets. In the animals implanted with cPs, no adverse effects were found in terms of food and water intake or growth compared with an intact, non-operated control group $(n=8)$. In addition, no differences were found in gene expressions (i.e., Dio3, $H r$, and Trh in hypothalamus and Tshb in pituitary) or plasma TSH, $\mathrm{T}_{3}$, and $\mathrm{T}_{4}$ concentrations between these two groups (data not shown).

In order to validate the anatomy of the punches, we assessed oxytocin (Oxt) mRNA, which is PVN-specific
(Swanson \& Sawchenko 1983) and steroid factor 1 (Sf1) mRNA, which is VMH-specific (Roselli et al. 1997). As shown in Fig. 2C, Oxt mRNA was expressed 1000-fold less in the VMH compared with the PVN. In contrast, Sf1 mRNA expression was expressed over 20-fold higher in the VMH compared with the PVN (Fig. 2D), supporting the selectivity of the anatomical punches.

\section{Tissue $\mathrm{T}_{3}$ concentrations in the $\mathrm{PVN}$ and $\mathrm{VMH}$}

We then evaluated the local $\mathrm{T}_{3}$ concentration after 28 days of implantation in micro-dissected PVN and VMH punches. As expected, local $\mathrm{T}_{3}$ concentrations were much higher in the $\mathrm{T}_{3} \mathrm{P}$-treated group compared with the $\mathrm{cP}$ group. $\mathrm{T}_{3}$ concentrations increased 90-fold in the PVN region and 50-fold in the $\mathrm{VMH}$ region compared with the $\mathrm{cP}$ group when the $\mathrm{T}_{3} \mathrm{Ps}$ were placed in the PVN or VMH respectively (Fig. 3). When $\mathrm{T}_{3} \mathrm{Ps}$ were placed in the PVN, we also observed increased $\mathrm{T}_{3}$ in the $\mathrm{VMH}$ compared with the cP group (Fig. 3A), although to a much lesser extent than in the PVN. When $T_{3}$ Ps were placed in the $V M H$, no increased $T_{3}$ concentrations in the PVN were observed. In fact, $\mathrm{T}_{3}$ concentrations were even significantly lower compared with the $\mathrm{cP}$ group (Fig. 3B).

\section{Differential effect of $\mathrm{T}_{3}$ administration in the PVN and $\mathrm{VMH}$ on $\mathrm{T}_{3}$-responsive genes}

We assessed the effects of local $\mathrm{T}_{3}$ administration according to the mRNA expression of $\mathrm{T}_{3}$-responsive genes in the targeted nuclei. When implanting the $\mathrm{T}_{3} \mathrm{Ps}$ in the PVN, both Dio3 and $\mathrm{Hr}$ mRNA expressions were significantly increased in the PVN region, whereas Dio3 and $\mathrm{Hr}$ mRNA expressions in the $\mathrm{VMH}$ region were not affected (Fig. 4A and $\mathrm{B})$. Conversely, placement of $\mathrm{T}_{3} \mathrm{Ps}$ in the $\mathrm{VMH}$ induced a significant increase in Dio3 and $H r$ mRNA in the VMH region, but not in the PVN region (Fig. 4C and D). Gene expression was not different between intact animals and animals implanted with cPs (data not shown).

\section{Effect of $\mathrm{T}_{3}$ administration in the PVN on HPT axis}

Placement of $\mathrm{T}_{3} \mathrm{Ps}$ in the PVN did not change Trh mRNA in the PVN or VMH region, while decreasing pituitary Tshb mRNA expression $(p<0.001)$ (Fig. 5A and B). There was no significant effect on plasma TSH concentrations (Fig. 5C). Plasma $\mathrm{T}_{3}$ concentrations were significantly decreased in rats with $\mathrm{T}_{3}$ Ps in the PVN at day 3,14 , and 21 after implantation, whereas plasma $\mathrm{T}_{4}$ concentrations were decreased at days 3 and 28 (Fig. 5D and E).

Published by Bioscientifica Ltd 
A

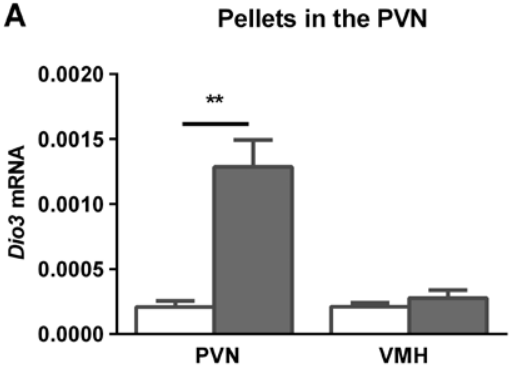

C

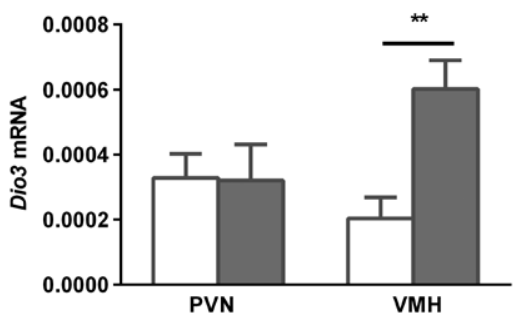

B

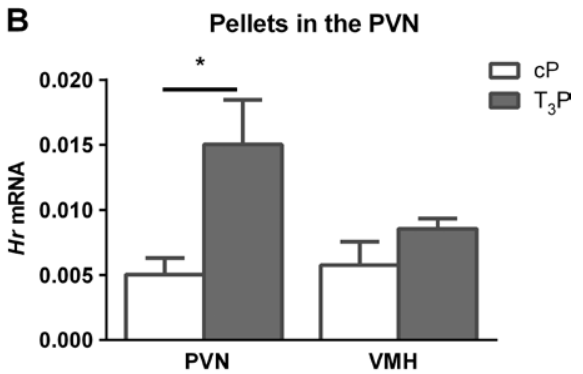

D

Pellets in the VMH

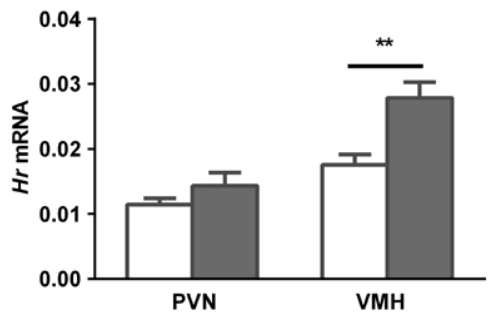

Figure 4

The mRNA expression of Dio3 and $\mathrm{Hr}$ in the PVN and VMH. (A and B) Pellets placed in the PVN, (C and D) Pellets placed in the VMH. $n=8-10$ per group. $* P<0.05, * * P<0.01$.

\section{Effect of $\mathrm{T}_{3}$ administration in the VMH on HPT axis}

Placement of $\mathrm{T}_{3}$ Ps in the VMH did not change Trh mRNA in the PVN; however, it decreased Trh mRNA in the VMH region (Fig. 6A). As expected, pituitary Tshb mRNA, plasma TSH (Fig. 6B and C), and plasma TH (Fig. 6D and $\mathrm{E}$ ) concentrations did not change throughout the time course of this experiment.

\section{Discussion}

This study shows that it is feasible to selectively deliver $\mathrm{T}_{3}$ for 4 weeks to the PVN or the VMH, without leakage of $\mathrm{T}_{3}$ into the systemic circulation. Also within the hypothalamus, diffusion was limited, as $\mathrm{T}_{3}$-containing pellets in the PVN did not affect $\mathrm{T}_{3}$-responsive gene expression in the $\mathrm{VMH}$ or vice versa. As expected, chronic $\mathrm{T}_{3}$ administration in the PVN, but not in the VMH, decreased pituitary Tshb mRNA expression as well as plasma $\mathrm{T}_{3}$ and $\mathrm{T}_{4}$ concentrations.

To set up the experimental model, we first performed pilot experiments in vitro. Incubation of $\mathrm{T}_{3} \mathrm{P}$ in plasma resulted in rather constant $\mathrm{T}_{3}$ concentrations in the physiological range for more than 1 month. Subsequently, we implanted the pellets into specific hypothalamic nuclei, followed by assessment of local tissue $\mathrm{T}_{3}$ concentrations in hypothalamic tissue punches. The anatomical selectivity of the punch technique was confirmed by the selective expression of $O x t$ and $S f 1$ in either the PVN or the VMH respectively. Twenty-eight days after placement of $\mathrm{T}_{3} \mathrm{Ps}, \mathrm{T}_{3}$ concentrations increased 90 -fold in the PVN region and 50-fold in the VMH region compared with $\mathrm{cP}$ when $\mathrm{T}_{3} \mathrm{Ps}$ were placed in the PVN or VMH respectively. Although the local $\mathrm{T}_{3}$ concentration was somewhat higher in the VMH after implantation of $\mathrm{T}_{3}$ Ps in the PVN, this did not induce $\mathrm{T}_{3}$-responsive gene expression. These results show that $\mathrm{T}_{3} \mathrm{P}$ released $\mathrm{T}_{3}$ in a rather limited anatomical region for more than a month.

Next, we investigated the effects of $T_{3}$ administration by assessment of $\mathrm{T}_{3}$-responsive gene expression. Dio3 is a $\mathrm{T}_{3}$-sensitive gene coding for a deiodinating enzyme that is critical in maintaining local TH homeostasis (Dentice \& Salvatore 2011). As a main physiological inhibitor of $\mathrm{TH}$ action, it protects cells from excessive TH by converting $\mathrm{T}_{3}$ (or $\mathrm{T}_{4}$ ) into its inactive derivatives, $\mathrm{T}_{2}$ ( or $\mathrm{T}_{3}$ ) (Dentice and Salvatore 2011). In rats, Dio3 mRNA expression was shown to increase in the brain during hyperthyroidism, while it was undetectable during hypothyroidism (Tu et al. 1999, Bianco et al. 2002). In line with these observations, the present experiments showed that Dio3 mRNA was only increased in the PVN but not in the VMH when the $\mathrm{T}_{3} \mathrm{Ps}$ were placed in the PVN, while Dio3 mRNA was only increased in the VMH but not in the PVN when the $\mathrm{T}_{3} \mathrm{Ps}$ were placed in the VMH. Of note, Dio3 mRNA expression may be enhanced by neuronal injury (Li et al. 2001). However, Dio3 mRNA expression in non-operated rats did not differ from rats implanted with cPs, which excludes an effect of tissue damage by the pellet itself. In addition to Dio3, expression of $H r$, which is another well-known $\mathrm{T}_{3}$-responsive gene (Potter et al. 2002), was significantly increased only in the target nuclei where the $\mathrm{T}_{3}$ Ps were placed, again suggesting a nucleus-specific $\mathrm{T}_{3}$

Published by Bioscientifica Ltd 

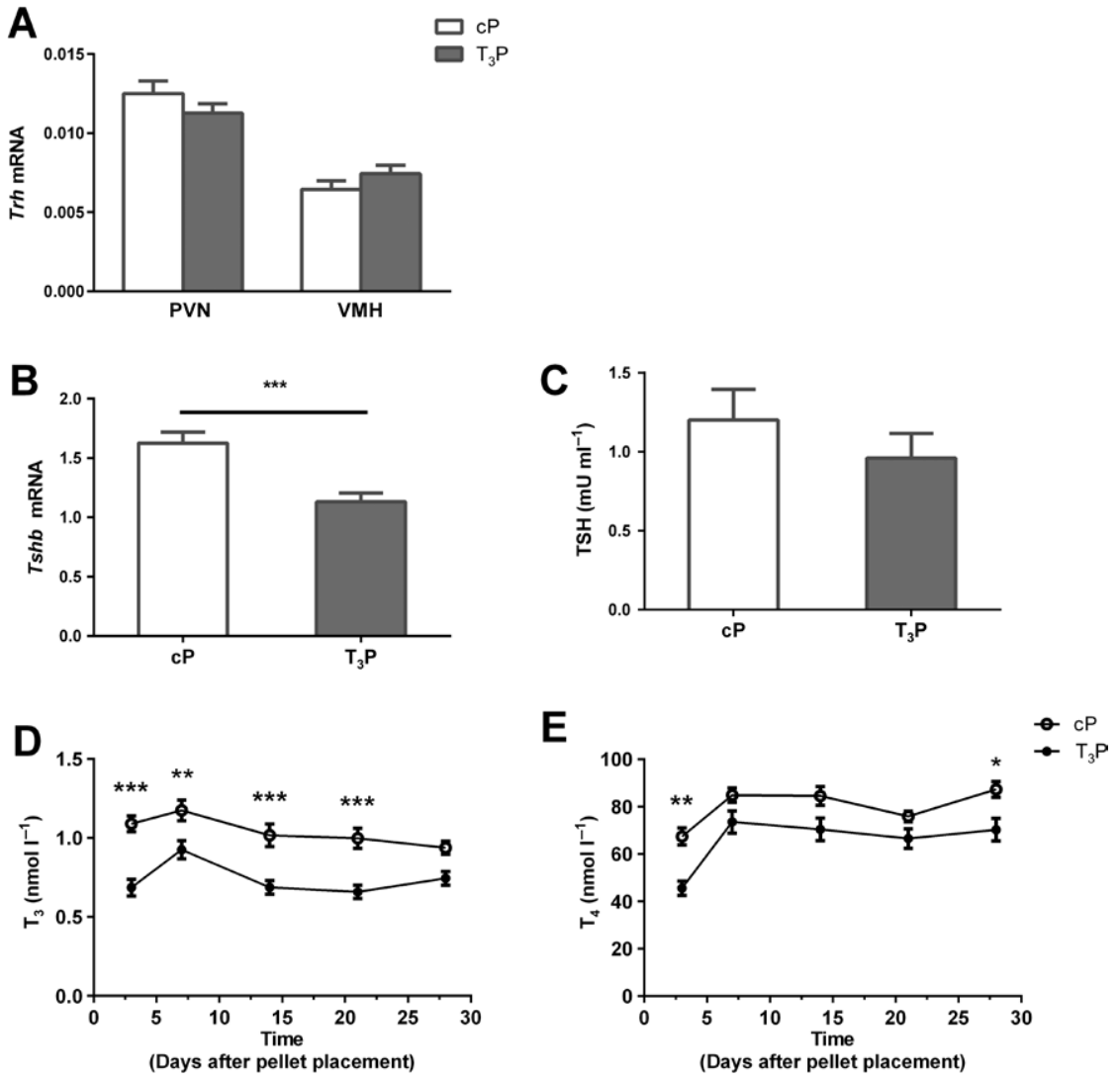

Figure 5

HPT axis response to $T_{3}$ administration in the PVN. (A) Trh mRNA in the PVN and VMH, (B) Tshb mRNA in pituitary gland, (C) plasma TSH, (D) Plasma $\mathrm{T}_{3}$ and (E) Plasma $\mathrm{T}_{4}$ concentrations. $n=8-10$ per group. ${ }^{*} P<0.05, * * P<0.01, * * * P<0.001$. response as a result of locally increased $\mathrm{T}_{3}$ concentrations. A few additional reported $\mathrm{T}_{3}$-responsive genes such as oxytocin (Oxt) (Dellovade et al. 1999) and monocarboxylate transporter 8 (Mct8 (Slc16a2)) (Herwig et al. 2014) did not show significant changes between control and $\mathrm{T}_{3}$-treated groups (data not shown). We did not observe any change in Trh mRNA expression measured by qPCR in a punch of the PVN region 28 days after placement of $\mathrm{T}_{3}$ Ps. A previous study using a hypothyroid rat model showed that unilateral $\mathrm{T}_{3}$ crystalline implants within the anterior hypothalamus induced a marked reduction of Trh mRNA only in the medial parvocellular division of PVN as shown by in situ hybridization within 4 days (Dyess et al. 1988). Moreover, a study by Murphy et al. (2012) showed a mild suppression of hypothalamic Trh mRNA assessed by in situ hybridization 6 weeks after $T_{3}$ implants in the hypothalamus of Siberian hamsters. Therefore, the absence of an effect on Trh mRNA in the PVN after $\mathrm{T}_{3}$ administration to the PVN in our study can probably be explained by the fact that only a subpopulation of TRH neurons in the PVN, i.e., the hypophysiotropic TRH neurons, are responsive to $\mathrm{T}_{3}$ (Segerson et al. 1987, Fekete \& Lechan 2014). In our approach, using the whole PVN region for qPCR, selective changes in the subpopulation of hypophysiotropic TRH neurons may have gone unnoticed as all TRH neurons in the micro-punch are included in the PCR assessment.

Pituitary $T s h b$ mRNA was lower after 28 days in the PVN in $\mathrm{T}_{3} \mathrm{P}$ group compared with rats with cPs, in accordance with negative feedback regulation (Fliers et al. 2014). Plasma TSH concentration, however, was not significantly altered. Of note, a previous study showed that $\mathrm{T}_{3}$ crystalline implants in the hypothalamus did not influence TSH secretion in hypothyroid rats, although IR-proTRH was remarkably inhibited (Dyess et al. 1988). The production and secretion of TSH by the pituitary gland are positively stimulated by TRH, while TRH also modulates the glycosylation of TSH, which affects TSH bioactivity (Magner 1990). Part of the explanation for unaltered plasma TSH in the presence of decreased pituitary Tshb mRNA as observed in this study may be a discrepancy between the biological activity and the immunological detectability of TSH (Persani \& Bonomi 2014).

In line with negative feedback at the central level and decreased pituitary Tshb mRNA after $\mathrm{T}_{3}$ Ps implantation in the PVN, plasma $T_{3}$ and $T_{4}$ concentrations were significantly decreased throughout the experiment. In summary, our results indicate that the $\mathrm{T}_{3} \mathrm{Ps}$ implantation in the PVN

Published by Bioscientifica Ltd. 
A
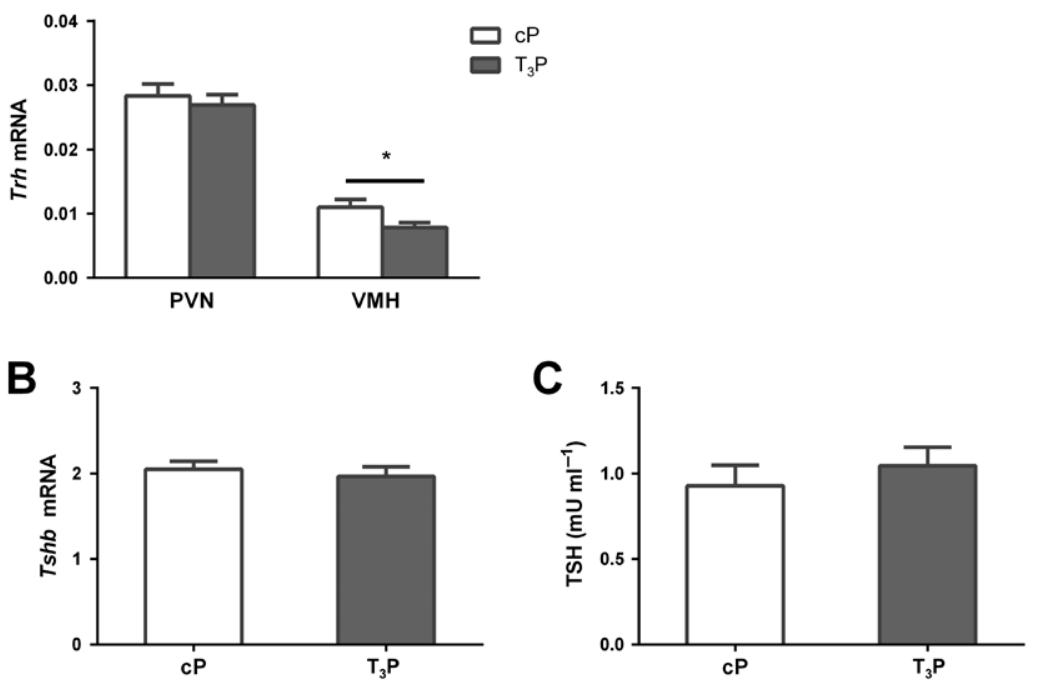

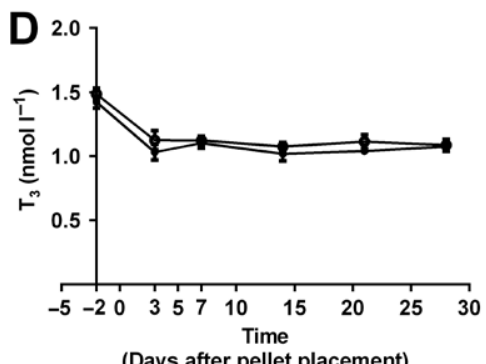

(Days after pellet placement)

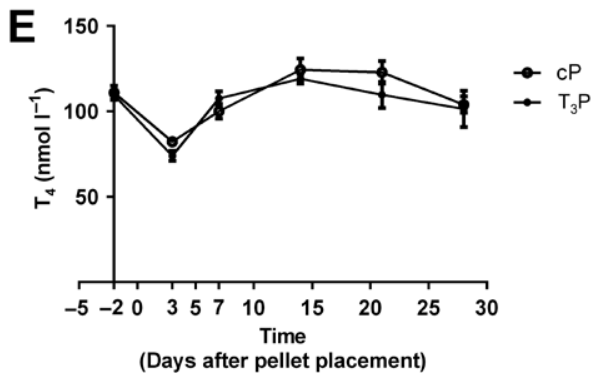

Figure 6

HPT axis response to $T_{3}$ administration in the VMH. (A) Trh mRNA in PVN and VMH regions,

(B) Tshb mRNA in pituitary gland, (C) Plasma TSH, (D) Plasma $\mathrm{T}_{3}$ and (E) Plasma $\mathrm{T}_{4}$ concentrations. $n=8-10$ per group. ${ }^{*} P<0.05$. delivers $\mathrm{T}_{3}$ locally for at least 28 days. As an autonomic nervous system integration center, the PVN is involved in many aspects of energy metabolism, including hepatic glucose production. The investigation of metabolic effects of chronic intrahypothalamic $\mathrm{T}_{3}$ administration in the PVN will be the focus of our future experiments.

Placement of $\mathrm{T}_{3}$ Ps in the VMH did not affect the HPT axis in any way, again supporting a locally restricted $\mathrm{T}_{3}$ administration. Recent experiments have shown that $\mathrm{TH}$ in the VMH is a powerful determinant of BAT activity (Lopez et al. 2013). Thus, we expect that the present technique will enable studies on long-term metabolic consequence of central $\mathrm{T}_{3}$ on energy balance in addition to glucose metabolism. Finally, as a recent study showed a novel central role for $\mathrm{T}_{3}$ in cardiovascular regulation by acting on a group of pre-autonomic neurons in the anterior hypothalamus (AH) (Mittag et al. 2013), our model may be helpful to study the long-term effects of $\mathrm{T}_{3}$ in the $\mathrm{AH}$ on blood pressure and heart rate as well.

In conclusion, our pilot experiments provide a promising technique to selectively deliver $T_{3}$ for at least 4 weeks to specific hypothalamic nuclei. The use of these $\mathrm{T}_{3}$-containing pellets holds promise for studies on metabolic effects of nucleus-specific chronic $\mathrm{T}_{3}$ delivery within the hypothalamus.

Declaration of interest

The authors declare that there is no conflict of interest that could be perceived as prejudicing the impartiality of the research reported.

Funding

This project was funded by a grant from the China Exchange Program (CEP) of the Royal Netherlands Academy of Sciences and the Chinese Academy of Sciences (grant \#11CDP001, to E.F.) and by a grant from the Chinese Scholarship Council (CSC) (CSC ID: 201206340004, to Z.Z.).

\section{Acknowledgements}

We would like to thank the staff of the Laboratory of Endocrinology for measuring serum thyroid hormones.

\section{References}

Bianco AC, Salvatore D, Gereben B, Berry MJ \& Larsen PR 2002 Biochemistry, cellular and molecular biology, and physiological roles of the iodothyronine selenodeiodinases. Endocrine Reviews 23 38-89. (doi:10.1210/edrv.23.1.0455)
(C) 2016 Society for Endocrinology Printed in Great Britain 
Dellovade TL, Zhu YS \& Pfaff DW 1999 Thyroid hormones and estrogen affect oxytocin gene expression in hypothalamic neurons. Journal of Neuroendocrinology 11 1-10. (doi:10.1159/000054473)

Dentice M \& Salvatore D 2011 Deiodinases: the balance of thyroid hormone: local impact of thyroid hormone inactivation. Journal of Endocrinology 209 273-282. (doi:10.1530/JOE-11-0002)

Dyess EM, Segerson TP, Liposits Z, Paull WK, Kaplan MM, Wu P, Jackson IM \& Lechan RM 1988 Triiodothyronine exerts direct cellspecific regulation of thyrotropin-releasing hormone gene expression in the hypothalamic paraventricular nucleus. Endocrinology 123 2291-2297. (doi:10.1210/endo-123-5-2291)

Fekete C \& Lechan RM 2014 Central regulation of hypothalamicpituitary-thyroid axis under physiological and pathophysiological conditions. Endocrine Reviews 35 159-194. (doi:10.2340/165019772050)

Fliers E, Kalsbeek A \& Boelen A 2014 Beyond the fixed setpoint of the hypothalamus-pituitary-thyroid axis. European Journal of Endocrinology 171 R197-R208. (doi:10.1530/EJE-14-0285)

Fliers E, Klieverik LP \& Kalsbeek A 2010 Novel neural pathways for metabolic effects of thyroid hormone. Trends in Endocrinology \& Metabolism 21 230-236. (doi:10.1016/j.tem.2009.11.008)

Herwig A, Campbell G, Mayer CD, Boelen A, Anderson RA, Ross AW, Mercer JG \& Barrett P 2014 A thyroid hormone challenge in hypothyroid rats identifies T3 regulated genes in the hypothalamus and in models with altered energy balance and glucose homeostasis. Thyroid 24 1575-1593. (doi:10.1089/thy.2014.0169)

Klieverik LP, Janssen SF, van Riel A, Foppen E, Bisschop PH, Serlie MJ, Boelen A, Ackermans MT, Sauerwein HP, Fliers E et al. 2009 Thyroid hormone modulates glucose production via a sympathetic pathway from the hypothalamic paraventricular nucleus to the liver. PNAS 106 5966-5971. (doi:10.1073/pnas.0805355106)

Klieverik LP, Sauerwein HP, Ackermans MT, Boelen A, Kalsbeek A \& Fliers E 2008 Effects of thyrotoxicosis and selective hepatic autonomic denervation on hepatic glucose metabolism in rats. American Journal of Physiology: Endocrinology and Metabolism 294 E513-520. (doi:10.1073/pnas.0805355106)

Li WW, Le Goascogne C, Ramauge M, Schumacher M, Pierre M \& Courtin F 2001 Induction of type 3 iodothyronine deiodinase by nerve injury in the rat peripheral nervous system. Endocrinology 142 5190-5197. (doi:10.1210/endo.142.12.8532)

Lopez M, Alvarez CV, Nogueiras R \& Dieguez C 2013 Energy balance regulation by thyroid hormones at central level. Trends in Endocrinology \& Metabolism 19 418-427. (doi:10.1016/j. beem.2014.04.004)

Lopez M, Varela L, Vazquez MJ, Rodriguez-Cuenca S, Gonzalez CR, Velagapudi VR, Morgan DA, Schoenmakers E, Agassandian K, Lage R et al. 2010 Hypothalamic AMPK and fatty acid metabolism mediate thyroid regulation of energy balance. Nature Medicine $\mathbf{1 6}$ 1001-1008.

Magner JA 1990 Thyroid-stimulating hormone: biosynthesis, cell biology, and bioactivity. Endocrine Reviews 11 354-385. (doi:10.1210/edrv-112-354)

Mittag J, Lyons DJ, Sallstrom J, Vujovic M, Dudazy-Gralla S, Warner A, Wallis K, Alkemade A, Nordstrom K, Monyer H et al. 2013 Thyroid hormone is required for hypothalamic neurons regulating cardiovascular functions. Journal of Clinical Investigation 123 509-516. (doi:10.1172/JCI65252)

Mullur R, Liu YY \& Brent GA 2014 Thyroid hormone regulation of metabolism. Physiological Reviews 94 355-382. (doi:10.1152/ physrev.00030.2013)

Murphy M, Jethwa PH, Warner A, Barrett P, Nilaweera KN, Brameld JM \& Ebling FJ 2012 Effects of manipulating hypothalamic triiodothyronine concentrations on seasonal body weight and torpor cycles in Siberian hamsters. Endocrinology 153 101-112. (doi:10.1210/ en.2011-1249)

Palkovits M 1973 Isolated removal of hypothalamic or other brain nuclei of the rat. Brain Research 59 449-450. (doi:10.1016/00068993(73)90290-4)

Persani L \& Bonomi M 2014 Chapter 27 - Uncertainties in endocrine substitution therapy for central endocrine insufficiencies: hypothyroidism. In Handbook of Clinical Neurology, pp 397-405. Eds MK Eric Fliers \& AR Johannes. Philadelphia, PA, USA: Elsevier. (doi:10.1016/B978-0-444-59602-4.00027-7)

Potter GB, Zarach JM, Sisk JM \& Thompson CC 2002 The thyroid hormone-regulated corepressor hairless associates with histone deacetylases in neonatal rat brain. Molecular Endocrinology 16 2547-2560. (doi:10.1210/me.2002-0115)

Roselli CE, Jorgensen EZ, Doyle MW \& Ronnekleiv OK 1997 Expression of the orphan receptor steroidogenic factor-1 mRNA in the rat medial basal hypothalamus. Molecular Brain Research 44 66-72. (doi:10.1016/ S0169-328X(96)00187-8)

Segerson TP, Kauer J, Wolfe HC, Mobtaker H, Wu P, Jackson IM \& Lechan RM 1987 Thyroid hormone regulates TRH biosynthesis in the paraventricular nucleus of the rat hypothalamus. Science 238 78-80. (doi:10.1126/science.3116669)

Sinha RA, Singh BK \& Yen PM 2014 Thyroid hormone regulation of hepatic lipid and carbohydrate metabolism. Trends in Endocrinology \& Metabolism 25 538-545. (doi:10.1016/j.tem.2014.07.001)

Sjogren M, Alkemade A, Mittag J, Nordstrom K, Katz A, Rozell B, Westerblad H, Arner A \& Vennstrom B 2007 Hypermetabolism in mice caused by the central action of an unliganded thyroid hormone receptor alpha1. EMBO Journal 26 4535-4545. (doi:10.1038/ sj.emboj.7601882)

Swanson LW \& Sawchenko PE 1983 Hypothalamic integration: organization of the paraventricular and supraoptic nuclei. Annual Review of Neuroscience 6 269-324. (doi:10.1146/annurev. ne.06.030183.001413)

Tu HM, Legradi G, Bartha T, Salvatore D, Lechan RM \& Larsen PR 1999 Regional expression of the type 3 iodothyronine deiodinase messenger ribonucleic acid in the rat central nervous system and its regulation by thyroid hormone. Endocrinology 140 784-790. (doi:10.1210/endo.140.2.6486)

Warner A \& Mittag J 2012 Thyroid hormone and the central control of homeostasis. Journal of Molecular Endocrinology 49 R29-R35. (doi:10.1530/JME-12-0068)

Wiersinga WM \& Chopra IJ 1982 Radioimmunoassay of thyroxine $\left(\mathrm{T}_{4}\right)$, 3,5,3'-triiodothyronine (T3), 3,3',5'-triiodothyronine (reverse T3, rT3), and 3,3'-diiodothyronine (T2). Methods in Enzymology 84 272-303.

Received in final form 27 January 2016

Accepted 10 February 2016

Accepted Preprint published online 10 February 2016 http://joe.endocrinology-journals.org

DOI: 10.1530/JOE-15-0501
(C) 2016 Society for Endocrinology Printed in Great Britain
Published by Bioscientifica Ltd. 